most by those interested in applied acoustics, several important general works published since 1925 might with advantage be included in the bibliography. The six books given are scarcely representative, sources in English being represented solely by the Physical Society's discussion on audition. A list of more than two hundred periodicals which are to be searched for the bibliography is given as a supplement. The address of publication is Les Presses Universitaires de France, 47 Boulevard Saint-Michel, Paris 5e.

\section{Vocational Tests for School Children}

THe City of Birmingham Education Committee has published the results of an investigation by $\mathbf{E}$. Patricia Allen and Percival Smith into the value of vocational tests as aids to choice of employment (Treasurer's Department, Council House, Birmingham. 1s. net). Every child leaving school in Birmingham is carefully advised as to his future occupation, but it was felt that vocational tests might give the employment conferences more adequate data on which to base their suggestions. For the purpose of this experiment, the children leaving three schools were divided into two groups : one group was treated in the usual way, while the other was examined by special tests for manual, mechanical, and clerical ability, dress-making, and intelligence, and studies were added of social, medical, and temperamental conditions. The advice given was then based on the results. When the children had obtained work, there would be four categories, namely, the tested children who did and did not follow the advice, and the controls who did and did not. Evidence as to the progress of these groups in their industrial careers was then compiled over a period of two years. Although the report makes no extravagant claims, yet the general tendency was for the tested children, who were placed in accordance with the advice given, to be more satisfactorily placed than those in the other three categories. The writers report that a surprisingly large number of the parents had no ideas for their children, nor did the children as a rule know what they would like to do. The report is excellent, sufficient details being given, with the exception of the testing for temperament, to enable other workers to follow this up and use it for comparison. The results are in agreement with the previous London research.

\section{Tung Oil in the United States}

Tre establishment of the tung oil industry in the United States has been so successful during the last few years that a move is now being made to expand it on such a scale that America will cease to be dependent on China for even small quantities of this commodity. Dr.H. A. Gardner has recently described the position in a paper before the American Chemical Society (Science Service, Washington). Tung oil is essentially an oriental product, used through the ages by the Chinese for making native lacquer and ink. It is manufactured from the seeds of a deciduous tree, Aleurites, native to China, on much the same principle as peanut oil is produced by milling from peanuts

$$
\text { No. 3275, VoL. 130] }
$$

in that country. Seeds were first introduced into America through the agency of the U.S. Department of Agriculture in 1905, and planted at the Government Experimental Station then at Chico, California. Extensive plantings, however, were not made until some eight years ago in the southern States, which were so successful that already 25,000 acres of land have been given over to the industry. The American Paint and Varnish Association is particularly concerned with this venture, as the oil is a valuable ingredient of varnishes and varnish paints. Apart from these uses, the American industries have extended considerably the application of tung oil, and it is now employed in the manufacture of insulating compounds, brake linings, linoleum, waterproofing fabries, as a binder for wall board and plastic synthetic lumber, primers, synthetic resins, battery jar compounds, aeroplane tubing fillers, and so on.

\section{American Institute of Physics}

For several years, a movement has been on foot in the United States to bring about co-operation between the several American societies devoted to physics and its more immediate branches. This has recently had its culmination in the formation of the American Institute of Physies, comprising the American Physical Society, the Optical Society of America, the Acoustical Society of America, the Society of Rheology, and the American Association of Physics Teachers. The purposes of the Institute are subject, of course, to natural development in accordance with the future needs of its founder societies. For the present, its principal activity is the publication of journals. The societies are delegating to the Institute the responsibility for publishing the journals which they have in the past sponsored themselves. The reason for this course of action is the promotion of economy and efficiency. The list of the journals includes the Physical Review, Physics, Reviews of Modern Physics, Journal of the Optical Society of America, the Review of Scientific Instruments, Journal of the Acoustical Society of America, and Journal of Rheology. The scientific editing of the journals remains the duty of the societies, while all the details in the handling of proofs, subscription records, book-keeping, and the like are undertaken by the Institute. Two important other functions have been assigned to the Institute, namely, the further co-operation with societies and agencies outside the founding group, and the extension of an information service to the Press. The central office of the American Institute of Physics is at 11 East 38th Street, New York City.

\section{Manufacture of Insulators}

THE Vista is a periodical published by the British Porcelain Co., Ltd., London, S.W.1, and deals mainly with subjects of interest to the electric power industry. In the May number it concludes a series of articles on insulator manufacture. Each piece of electrical porcelain is carefully inspected by factory inspectors immediately after removal from the kiln, and all pieces failing to pass this inspection are destroyed. To find the porosity, fragments of the porcelain are 
placed in fuchsine dye and subjected to a pressure of two thousand pounds per square inch for twenty-four hours. They are then removed, carefully dried, and broken to find out whether there is 'penetration' or not. If any is noticed, the representative batch of insulators is destroyed. The thermal test consists in immersing the porcelain in boiling water and then in iced water for periods of ten minutes, one hot and one cold test constituting a thermal cycle. After five such cycles, the porcelain is flashed over to test for thermal failure. After further thermal cycles, the insulators are subjected to a flashover test. They are next subjected to a flashover test at a frequency of 250,000 cycles per second. This test has proved a boon to the industry, as it eliminates porcelain with dielectric defects. In assembling the insulators, Portland cement with a definite proportion of pure water is used. They are allowed to stand five days before being cleaned and treated with weather-proofing compound, and after three more days a routine tension test is applied. The final tests are made in the presence of the customers' inspector, who sees the large completed insulator subjected to a load of $10,000 \mathrm{lb}$. weight and to a highfrequency flashover.

\section{The Census of India}

IN a paper read to the Royal Society of Arts on June 3, Dr. J. H. Hutton discussed some of the figures of the Indian census of 1931. Perfect accuracy in enumeration is not to be expected, and in this census there were certain unusual difficulties. From estimates based on those regions where the census was known to be incomplete for reasons that can be traced, it may be assumed that the deficiency for the whole of India is not more than one per mille. It was calculated that the normal increase in the decade 1921-31 should have been 8 per cent, or rather less if allowance were made for the last influenza epidemic and its inroads on population of the reproducing age. The actual increase, however, proved to be $10 \cdot 6$ per cent, a rate exceeding any previous record. The increase was greatest in the Native States and apparently has been most marked in the less fertile parts of the country, which is an indication of the pressure on agricultural land. In some cases, heavy increases have been due to an extension of irrigation. The lowest density came from certain districts of Baluchistan and the highest from part of Cochin, where the density exceeds even that of Java. There has been little change in the general proportion of urban to rural population. In 1931 the total percentage of urban population was $11 \cdot 0$ per cent as compared with $10 \cdot 2$ per cent in 1921 . The proportion of females to males is falling and is now 940 females to every 1000 males.

\section{Announcements}

THE Medical Research Council has appointed Mr. Ermest Bevin, Dr. C. G. Douglas, and Mr. W. S. Morrison, M.P., to be members of the Industrial Health Research Board in succession to Mr. Arthur Pugh, Prof. E. P. Catheart, and Major A. G. Church, who retire by rota on Sept. 30 .
AT the quarterly comitia of the Royal College of Physicians of London held on July 28, the Bisset Hawkins Gold Medal was awarded to Dr. T. H. C. Stevenson for his work as superintendent of statistics in the office of the Registrar-General. It was also announced that the Harveian Oration will be delivered by Sir George Newman, Chief Medical Officer of the Ministry of Health and Board of Education, on Oct. 18.

AT a meeting of the Council of the North-East Coast Institution of Engineers and Shipbuilders, held on July 22, the following medals were awarded: the Engineering Gold Medal to Messrs. L. J. Le Mesurier and R. Stansfield, for a paper entitled " Combustion in Heavy Oil Engines "; the Shipbuilding Gold Medal to Dr. F. H. Todd, for a paper entitled "Some Measurements of Ship Vibration"; the Thomas Fenwick Reed Medal, "for ability to take a share in the control of industry ", to Mr. W. Spencer Paulin. The first Andrew Laing Memorial Lecture of the Institution will be delivered on Oct. 28, by Eng. ViceAdmiral Sir R. W. Skelton, Engineer-in-Chief of the Fleet.

IT was announced at the annual meeting of the Wiltshire Archæological Society, which was held at Malmesbury on July 26, that the outgoing president, Mrs. M. E. Cunnington, in conjunction with her husband, Capt. B. H. Cunnington, had offered the nation the now famous prehistoric sites of Woodhenge, near Stonehenge, and the Sanctuary, near Avebury. These sites were purchased and excavated by Capt. and Mrs. Cunnington after their discovery from the air. They have since been fenced and the ring of post holes, in which the wooden, and in the latter wooden and stone posts, formerly stood, marked by low concrete pillars, showing the plan of the monuments. This generous offer has been accepted by the Office of Works.

Applications are invited for the following appoint. ments, on or before the dates mentioned:-An assistant lecturer and demonstrator in civil engineering at the University College of South Wales and Monmouthshire, Cardiff-The Registrar (Aug. 8). An assistant for abstracting scientific and technical papers at the Department of Scientific and Industrial Research, 16 Old Queen Street, S.W.1.-The Secretary (Aug. 8). An assistant engineer in the Harbour Engineer's Department, Colombo Port Commission, Ceylon-The Crown Agents for the Colonies, 4 Millbank, Westminster, S.W.1 (Aug. 8). A curator at the Art Gallery and Museum, Doncaster-The Town Clerk, Town Clerk's Office, Doncaster (Aug. 9). Junior scientific officers in the Scientific Research Pool, Air Ministry-The Chief Superintendent, Royal Aircraft Establishment, South Farnborough, Hants (Aug. 18). An engineering assistant for the Portsmouth Water Company-The Engineer, Water Company's Office, 26 Commercial Road, Portsmouth (Aug. 22). A principal at the Kadoorie Jewish Agricultural School, Mount Tabor, Palestine-The Chief Secretary to the Government of Palestine, Jerusalem (Aug. 30). 